\title{
Landfill sustainability and aftercare completion criteria
}

\author{
Heijo Scharff ${ }^{1}$ \\ Andre' van Zomeren ${ }^{2}$ \\ Hans A van der Sloot ${ }^{3}$ \\ ${ }^{1}$ Afvalzorg Deponie BV, The Netherlands. \\ ${ }^{2}$ ECN, Environmental Risk Assessment, The Netherlands. \\ ${ }^{3}$ Hans van der Sloot Consultancy, The Netherlands.
}

Published in Waste Management \& Research 29(1) 30-40 


\title{
Landfill sustainability and aftercare completion criteria
}

\author{
Heijo Scharff ${ }^{1}$, André van Zomeren ${ }^{2}$ and Hans A van der Sloot ${ }^{3}$
}

@SAGE

\begin{abstract}
Although many countries are increasing their efforts to recycle and to re-use waste materials, landfilling will still be needed in order to dispose of wastes which cannot be recycled or treated in other ways. Since landfills will most probably be present for a long time, measures will have to be taken to reduce their (long-term) emissions. The European Commission has delegated the competent authorities to decide to end aftercare and several member states have provided regulations for this purpose. However, there is currently no guidance for long-term risk assessment to support an aftercare completion procedure for landfills. The aim of this study is to provide examples of current regulations and to demonstrate an alternative approach for a quantitative risk assessment of landfill leachate. The presented modelling approach clearly demonstrates the added value of site specific risk assessments of the long-term emissions from landfills and might provide a basis for application when the acceptance criteria for landfill will be revisited in the future. In addition, the modelling approach can be used as one of the toolboxes to perform assessments of the long-term emissions from landfill leachates and might help the competent authorities to decide whether the remaining emission potential is acceptable or not. Moreover, the results imply that local environmental conditions contribute to the acceptability of landfill emissions and are important factors in choosing a landfill location.
\end{abstract}

\section{Keywords}

Landfill, sustainability, aftercare, completion, criteria

Date received: 12 June 2010; accepted: 18 August 2010

\section{Introduction}

Although many countries are increasing their efforts to recycle and to re-use waste materials, landfilling will still be needed in order to dispose of wastes which cannot be recycled or treated in other ways. In addition, landfills will be among us for a long time and measures will have to be taken to reduce their (long-term) emissions. Therefore, both the environmental as well as the financial impact of landfills need to be assessed and concepts that increase the sustainability of this waste management option are under development (Luning et al. 2006, Mathlener et al. 2006, van Zomeren \& van der Sloot 2006a, van der Sloot et al. 2007, van Zomeren et al. 2009). However, sustainability is not a clear concept and in relation to the landfill of waste it causes opposition among regulators and the general public.

Common use of the term sustainability began with the report of the World Commission on Environment and Development, entitled Our Common Future (WCED 1987). This document coined the well-known and widely referenced definition of sustainable development as 'development that meets the needs of the present without compromising the ability of future generations to meet their own needs'. Although the general concept of sustainability is being increasingly embraced by the waste management industry, regulators, environmentalists, and the general public, shared definitions of 'sustainable landfill' and 'landfill stability' were until recently not available.

The landfill industry and the regulators essentially need a definition of sustainability, stability or acceptable risk in order to agree on aftercare completion. Aftercare completion is the moment at which the responsibility for the remaining

\footnotetext{
${ }^{1}$ Afvalzorg Deponie BV, PO Box 2, 1566 ZG, Assendelft, The Netherlands.

${ }^{2}$ ECN, Environmental Risk Assessment, P.O. Box 1, 1755 ZG Petten, The Netherlands.

${ }^{3}$ Hans van der Sloot Consultancy, Dorpsstraat 216, 1721 BV Broek op Langedijk, The Netherlands.
}

\section{Corresponding author:}

Heijo Scharff, Afvalzorg Deponie BV, PO Box 2, 1566 ZG, Assendelft, The Netherlands

Email: h.scharffaafvalzorg.nl 
risk of a landfill is transferred from the operator to society, meaning any organization that is willing to accept the remaining risk and emission potential. The key issue is more about a desired 'end-point', risk and risk assessment than about sustainability. In that respect it seems more important to emphasize striving for acceptable risk rather than achieving sustainability.

The term functional stability was proposed in 2004 by the SWANA Bioreactor Committee Stability Subcommittee (Barlaz M.A. (2005): personal communication): 'A landfill is functionally stable when the waste mass, post-closure, does not pose a threat to human health and the environment. This condition must be assessed in consideration of leachate quality and quantity; gas composition and production; cover, side-slope and liner design; site geology and hydrogeology; climate; potential receiving bodies, ecosystems and human exposure; and other factors deemed relevant on a site-specific basis. Functional stability should be assessed in the context of a proposed end use and a proposed level of post-closure care, which may vary from no care, to some level of ongoing maintenance or monitoring that is designed to assure that no factors change that could increase potential threats to human health and the environment.'

Consequently, the risk of a landfill can only be assessed for a specified situation and after-use. Considering the above, a group of international scientists (Scharff 2009) recently agreed on the following definition (or framework) of acceptable risk for landfills in the context of aftercare completion.

(1) The landfill reaches functional stability (based on sitespecific physical, chemical, and biological characteristics of the waste mass and its location) such that the landfill, taking into account its proposed after-use, is unlikely to pose an unacceptable risk to human health or the environment.

(2) During the process towards functional stability no unacceptable risk should occur.

(3) This situation should be reached as quickly as possible and within the financial provision time.

(4) The funding for completion of aftercare has been secured and allows for appropriate after-use of the site with minimal (custodial) care.

The European Commission has delegated to the competent authorities to decide to end aftercare (CEC 1999). Several member states have provided regulations as a basis for aftercare and aftercare completion of landfills (see Section 2). However, there is currently no guidance for long-term risk assessment to support an aftercare completion procedure for landfills. The aim of this study was to provide examples of current regulations and to demonstrate an alternative approach for a quantitative risk assessment of landfill leachate. It should be noted that the present study focused mainly on a possible approach for aftercare completion criteria of landfill leachate as part of the total assessment of parameters (e.g. gas emissions and functional stability) to come to a toolbox for an integrated aftercare completion procedure. The approach is based on data from an ongoing pilot study regarding the disposal of predominantly inorganic waste (van Zomeren and van der Sloot 2006a, Scharff et al. 2007, van Zomeren et al. 2009). The predictions of the long-term impact of the pilot landfill are based on a so called source-pathway-receptor approach, similar to the conceptual model that was used for calculation of the waste acceptance criteria in the Landfill Directive (Hjelmar et al. 2001). The major difference with the current approach is that the modelling is now based on reactive transport of contaminants through the soil towards a point of compliance.

\section{Regulatory context}

Reaching landfill stability, sometimes addressed as final storage quality, is implicitly assumed in many landfill regulations (Scharff et al. 2007). However, strategies and means to achieve landfill stability have not yet been included in landfill regulations and guidelines (Hjelmar \& Bjerre Hansen 2005). The European Commission continues to emphasize that the guiding principle for waste regulation is to guarantee the protection of the environment and of human health. In the Thematic Strategy on the prevention and recycling of waste (CEC 2005) and the Waste Framework Directive (CEC 2008) it is expressed to give more attention to risk assessment and life-cycle thinking.

Article 13(d) of the European Landfill Directive (CEC, 1999) states: ' . . f for as long as the competent authority considers that a landfill is likely to cause a hazard to the environment..., the operator of the site shall be responsible for monitoring and analysing landfill gas and leachate... and groundwater regime in the vicinity of the site...' Accordingly, aftercare cannot be ended, or in other words landfill aftercare completion cannot be agreed upon, until the competent authority can be convinced that the landfill is no longer causing a hazard. The Directive provides no guidance on when and how to end aftercare. As a result, landfill operators are uncertain about the actions to take to work towards landfill aftercare completion and what financial reserves they should make concerning aftercare.

Article 2(e) of the European Landfill Directive (CEC 1999) states: "inert waste' means waste that does not... adversely affect other matter with which it comes into contact in a way likely to give rise to environmental pollution or harm human health. The total leachability and pollutant content of the waste and the ecotoxicity of the leachate must be insignificant, and in particular not endanger the quality of surface water and/or groundwater". The European Landfill Directive does not require isolation and aftercare for landfills for inert waste. In combination with the statement that inert waste does not give rise to environmental pollution or harm 
human health, this implies that the emission associated with inert waste is considered acceptable (Scharff et al. 2007).

The European acceptance criteria for inert waste on landfills are leaching limit values (CEC 2003). They are based on compliance with drinking water standards in the groundwater (Hjelmar et al. 2001) at a point of compliance near the landfill taking into consideration all the processes below the landfill (Figure 1). Scharff et al. (2007) state that the European Commission has indirectly defined acceptable emissions as a landfill which meets the acceptance criteria for inert waste. However, the defined acceptance criteria are currently based on acceptance of individual waste materials before these are landfilled. Any criteria that define acceptable emissions, functional stability or end-point criteria need to be based on an assessment of the long-term emissions from the complete landfill at some point in time.

The impact of the European Groundwater Directive (CEC 2006) on landfill in general and end-point criteria in particular is not clear. It addresses water catchment areas in which landfills are a point source. The Dutch environment ministry has studied the European Groundwater Directive and concluded that it does not require a revision of the Dutch landfill regulations (VROM 2007). The European Groundwater Directive regulates maximum nitrogen levels in groundwater. Consequently it could require introduction of limit values for nitrogen in landfill regulations. According to various researchers (e.g. Kruempelbeck \& Ehrig 1999) nitrogen might extend landfill aftercare up to centuries, but nitrogen is not regulated in the European Landfill Directive.

The German Bundesministerium für Umwelt, Naturschutz und Reaktorsicherheit has recently issued a new integrated landfill directive (BMU 2009). This directive contains a paragraph about aftercare and release from aftercare of landfills. Landfills can be released from aftercare if they do not endanger the well-being of society and in particular do not endanger the groundwater protection. The criteria for the competent authority to assess this situation are to a large extent related to degradation of organic matter and stability of the landfill. The emission criteria for leachate are principally based on concentrations. Stegmann et al. (2006) propose that in some situations fluxes should be considered rather than concentrations, but due to existing German groundwater regulations this is hard to apply in reality. The risk assessment aspect is included in the process to determine the emission criteria. These criteria are independent of site-specific conditions. This implies that the protection of health and environment can only be guaranteed if the safety margins in the criteria are so wide that they will

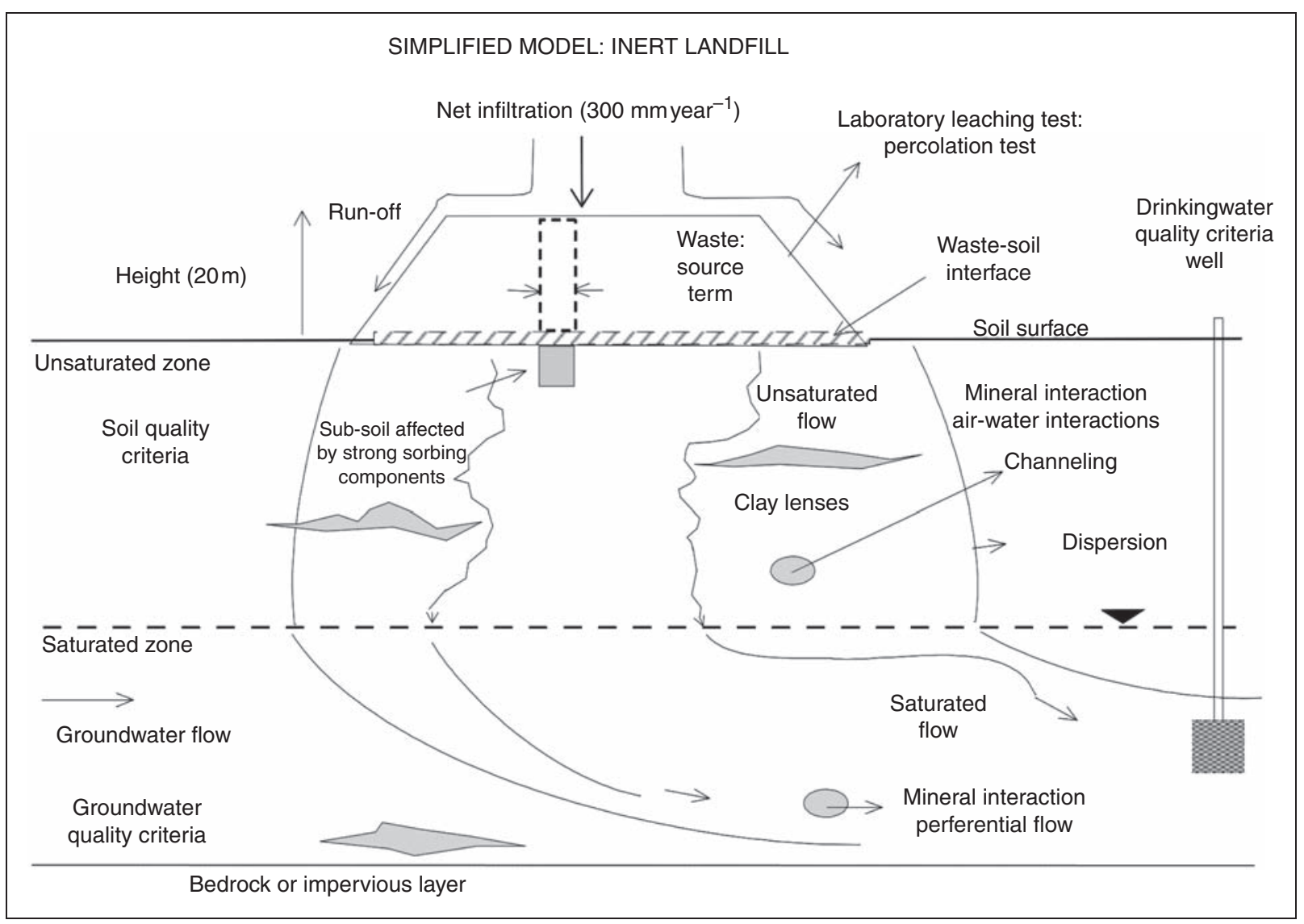

Figure 1. Scenario description for emissions of contaminants from a landfill to groundwater. The point of compliance is represented by a drinking water well (from Scharff et al. 2007). 
protect any environment. This could mean that in specific situations the criteria are too stringent and result in unnecessary costs for society. Scharff et al. (2007) consider the advantage of this approach is that it is very clear to all stakeholders what the criteria for release from aftercare are. The directive also contains options to deploy measures to accelerate landfill stabilization. The combination of clear criteria and stabilization measures make it relatively easy for landfill operators to decide on investments for accelerated landfill stabilization.

The United Kingdom has provided a draft document called Guidance on Landfill Completion and Surrender (Environment Agency 2005). The overall objective of this guidance is to ensure that sites remain under regulatory control until there is no longer a need for such control and more specifically to ensure that surrender of the authorization does not take place until the Agency considers that the landfill no longer poses a pollution risk. Risk assessment is an important element of the surrender process. The document specifies that the risk assessment should be a source-pathway-receptor method. Completion criteria will be site-specific. They will not necessarily be simple numerical values and may require a combination of factors to be present over a defined period of time. The guidance document provides examples of factors relating to the source term of environmental risk that should be considered. The risk assessment should provide predictions of the impact at each receptor as well as inputs and outputs of risk assessment modelling parameters. Scharff et al. (2007) consider this guidance very useful in that it provides options to include site-specific situations. It also offers operators room to apply the optimal methods to accelerate stabilization. It seems the operators have to choose their risk assessment method themselves. The final environmental targets are not entirely clear for the operators until the competent authority has authorized the surrender. Therefore, it may be rather difficult to make decisions to actively influence potential emission reduction and stability during operation and aftercare periods.

\section{Approaches for sustainable landfilling}

An essential element of sustainable methods for landfilling is rapid stabilization of the waste with which the landfill is constructed. Stabilization can be accelerated by optimal use of naturally occurring processes. These processes are different for different types of waste. This means that certain waste materials should receive a dedicated sustainable landfill approach. This concept was developed in the Dutch sustainable landfill project (Luning et al. 2006, Mathlener et al. 2006, van Zomeren et al. 2006, van Zomeren and van der Sloot, 2006a, b) and the idea that several types of waste can be processed in different landfill concepts (Figure 2) was later proposed during a workshop of the Inter Continental Landfill Research Symposium (Scharff 2006).

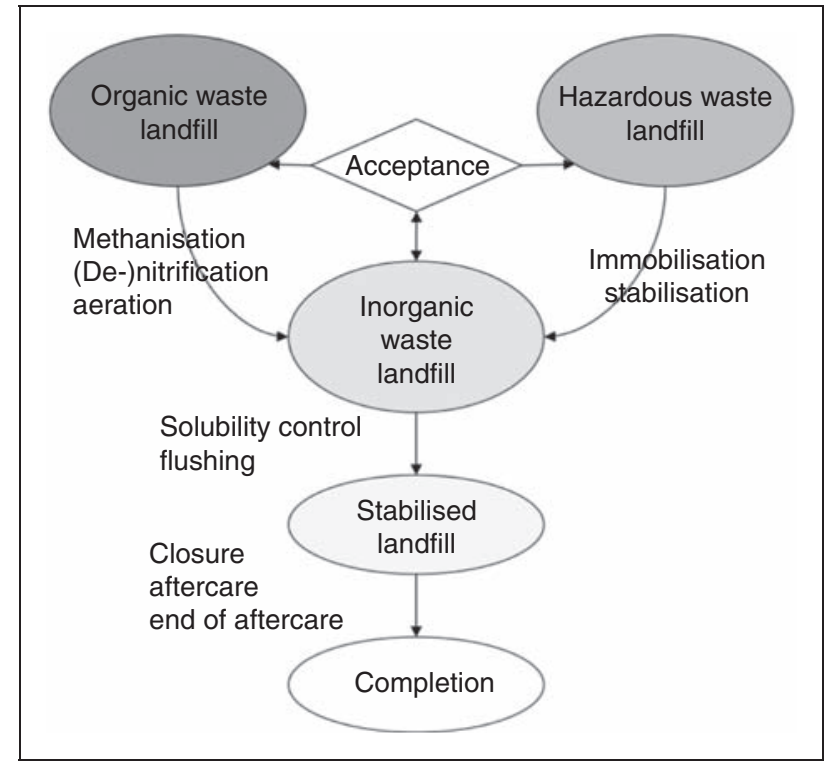

Figure 2. Relationships between different concepts for sustainable landfilling of organic, hazardous and predominantly inorganic waste materials (from Mathlener et al. 2006).

(1) The Bioreactor approach for biodegradable wastes. This approach aims at acceleration of the biodegradation processes. This is mainly achieved by means of injection and recirculation of water. Methane production is stimulated and capture rates are optimized. This results in a very low methane emission and optimized energy recovery.

(2) The Equifill approach for predominantly inorganic wastes. Specific types of inorganic wastes can neutralize each other's negative effects. Processes such as adsorption and precipitation can be stimulated based on better knowledge of the waste materials. This results in irreversible storage inside the landfill body and consequently to lasting low levels of emission.

(3) The Monolith approach for hazardous wastes. Contaminants in certain types of hazardous waste can be immobilized in minerals by mixing them in a dedicated immobilization plant. Mineralization can be optimized with a binding agent. A new material emerges that has monolithic properties. This material can either be applied as blocks or in layers to build a Monolith Landfill. The treatment results in lasting low levels of emission.

When most of the organic carbon in a bioreactor has been degraded, it is envisioned that the behaviour of the landfill body converges to the behaviour of an inorganic waste landfill (Mathlener et al. 2006). The same applies to (suitable types of) hazardous waste after immobilization or cement stabilization. For all types of waste on the road to aftercare completion it seems inevitable to 'pass through' a stage that is comparable to an inorganic waste landfill. Degradation having reached very low levels, the only remaining mechanisms for further reduction of potential emission are 
solubility control and flushing of mobile salts. The remaining level of emission from the stabilized landfill (in terms of organic matter degradation) can be considered marginal and isolation measures will no longer be required. It should be noted that the anticipated absence of isolation measures is most probably only feasible for the Bioreactor and Equifill concepts, whereas results from a stabilized hazardous waste pilot study (van Zomeren et al. 2007) indicate that the hazardous waste landfill needs to be isolated with liner systems. Samples taken after demolition of the 4-year-old pilot experiment showed that the uncovered cells were heavily weathered until a depth of $20-30 \mathrm{~cm}$. Numerous cracks were visible and the material had lost physical stability due to weathering processes and the wash-out of salts (enhanced porosity). The cell which was covered during the whole experiment (4 years) showed an increased physical stability and only minor indications of weathering (slight carbonation in the first $10 \mathrm{~cm}$ ). These results indicate that there is a need for long-term isolation of the stabilized hazardous waste landfill in order to ensure minimum salt release and to maintain physical stability.

When the long-term risks can be considered acceptable, this would also be the moment to formally end aftercare. Further involvement with the site depends on its intended after-use. For that reason 'functional stability' rather than absolute 'final storage quality' is considered appropriate. Aftercare could be minimized comparable to park maintenance. For this situation the term 'custodial care' has been introduced (ITRC 2006).

Various authors (e.g. Kruempelbeck \& Ehrig 1999; Stegmann et al. 2003) indicate that concentrations of chloride and nitrogen in leachate could exceed emission criteria centuries after closure of the landfill site. Consequently, it can be expected that groundwater impact of leachate will be of decisive influence during an aftercare completion procedure. The following paragraphs will, therefore, focus on groundwater impact. Obviously, the impact of landfill leachate on the environment is one of the building blocks of a complete risk assessment of landfills. In this study, other sources of emissions from landfills (e.g. odour, fugitive dust or methane) will not be addressed.

\section{Alternative approach to derive aftercare completion criteria}

In order to assess whether the protection of the environment and of human health is guaranteed (CEC 2005, 2008) in the long term it is inevitable to apply a risk assessment method that includes a reliable prediction of future groundwater impact. The European landfill regulations currently do not contain guidance for long-term risk assessment to support an aftercare completion procedure. In the Netherlands, the Dutch Environment Ministry, regional authorities and landfill operators are discussing an agreement to develop an aftercare completion procedure. The development will include a 5- to 10-year research programme to verify the elements of an aftercare completion procedure 'in the field'. Essential issues are the establishment of emission limit values and the assessment of the compliance of an entire landfill with these limit values. A method has to be developed. It is conceivable that an assessment method can consist of the following activities.

- An assessment of the historical and current landfill gas and leachate qualities and quantities and the hydrology of the waste body.

- Leaching and fermentation tests on waste samples from cores drilled into the waste body to provide data for modelling of long-term emission of the entire landfill.

- Statistical analyses (including confidence intervals) and modelling of the long-term emission potential and risk.

- Including local soil and groundwater conditions in the modelling and the assessment.

Recent developments in modelling (Meeussen 2003, Dijkstra et al. 2004, 2009, Verschoor et al. 2008, van Zomeren et al. 2009) indicate such an approach is feasible. The approach could rely to a large extent on the work carried out for the European waste acceptance criteria (Hjelmar et al. 2001). It is, however, necessary to define which aspects can and should be added and what level of reliability is required for prediction of future emissions.

\section{Comparison of landfill leachate emissions with acceptance criteria}

Leachate quality and leachate quantity data of an inorganic waste pilot project (Equifill) were used to calculate emissions (in $\mathrm{m} \mathrm{kg}^{-1}$ ). In the Equifill pilot project a cell of $12000 \mathrm{~m}^{3}$ was filled with residues from soil separation and cleaning, dredging sludge treatment and construction and demolition waste sorting and recycling. Further details on the waste input, cell construction and monitoring can be found in Scharff \& Jacobs (2005). The measured emissions from the pilot experiment were compared to limit values for waste acceptable at landfills for inert, non-hazardous and hazardous waste according to the Council Decision 2003/33/EC (CEC 2003) (Table 1). The Council Decision states two $L / S$ ratios for which limit values were determined $(L / S=2$ and $L /$ $S=10$ ). As the $L / S$ ratio of the pilot experiment is 0.9 , actual leachate quality is compared to the limit values at $L / S=2$. The Equifill leachate quality $(L / S=0.9)$ shows that most components do not exceed the limit values for waste acceptable at landfills for inert wastes so far. At first glance chloride and sulfate could be indicated as non-complying components. However, results obtained at $L / S=0.9$ and limit values obtained at $L / S=2$ cannot be directly compared. As a worst-case judgement, the emissions at $L / S=0.9$ could 
Table 1. Leaching data Equifill pilot and limit values EU Landfill Directive Annex II (from Scharff et al., 2007)

\begin{tabular}{|c|c|c|c|c|c|}
\hline Parameter & $\begin{array}{l}\text { Equifill } \\
\mathrm{L} / \mathrm{S}=0.9 \\
\left(\mathrm{mg} \mathrm{kg}^{-1}\right)\end{array}$ & $\begin{array}{l}\text { Column } \\
\mathrm{L} / \mathrm{S}=2 \\
\left(\mathrm{mg} \mathrm{kg}^{-1}\right)\end{array}$ & $\begin{array}{l}\text { Inert } \\
\mathrm{L} / \mathrm{S}=2 \\
\left(\mathrm{mg} \mathrm{kg}^{-1}\right)\end{array}$ & $\begin{array}{l}\text { Non-hazardous } \\
\mathrm{L} / \mathrm{S}=2 \\
\left(\mathrm{mg} \mathrm{kg}^{-1}\right)\end{array}$ & $\begin{array}{l}\text { Hazardous } \\
\mathrm{L} / \mathrm{S}=2 \\
\left(\mathrm{mg} \mathrm{kg}^{-1}\right)\end{array}$ \\
\hline As & 0.01 & 0.012 & 0.1 & 0.4 & 6 \\
\hline $\mathrm{Ba}$ & 0.17 & 0.11 & 7.0 & 30 & 100 \\
\hline $\mathrm{Cd}$ & 0.001 & 0.02 & 0.03 & 0.6 & 3 \\
\hline $\mathrm{Cl}$ & 901 & 3645 & 550 & 10,000 & 17,000 \\
\hline $\mathrm{Cr}$ & 0.01 & 0.004 & 0.2 & 4 & 25 \\
\hline $\mathrm{Cu}$ & 0.0005 & 0.003 & 0.9 & 25 & 50 \\
\hline DOC & 105 & 179 & 240 & 380 & 480 \\
\hline Mo & 0.01 & 0.014 & 0.3 & 5 & 20 \\
\hline $\mathrm{Ni}$ & 0.03 & 0.1 & 0.2 & 5 & 20 \\
\hline $\mathrm{Pb}$ & 0.01 & 0.06 & 0.2 & 5 & 25 \\
\hline $\mathrm{SO}_{4}$ & 1144 & 3629 & 560 & 10,000 & 25,000 \\
\hline $\mathrm{Sb}$ & 0.007 & 0.008 & 0.02 & 0.2 & 2 \\
\hline Se & 0.014 & 0.011 & 0.06 & 0.3 & 4 \\
\hline Zn & 0.018 & 0.5 & 2 & 25 & 90 \\
\hline$F$ & 0.220 & - & 4 & 60 & 200 \\
\hline TDS* & - & - & 2,500 & 40,000 & 70,000 \\
\hline $\mathrm{NH}_{4}{ }^{* *}$ & 65 & $?$ & $?$ & $?$ & $?$ \\
\hline $\mathrm{NO}_{3}{ }^{* *}$ & $?$ & $?$ & $100-200 * * *$ & $?$ & $?$ \\
\hline
\end{tabular}

Bold numbers exceed the EU limit values.

*The value for TDS (total dissolved solids) can be used alternatively to the values for sulphate and chloride (CEC, 2003).

**Annex II does not include nitrogen limit values. They will however be introduced by the future Groundwater Directive (CEC, 2006).

***Anticipated order of magnitude of the limit value.

be multiplied by a factor 2 to enable comparison with the limit values. In practice, this correction would lead to a slight overestimation of the emissions since the leached amounts are already starting to decline above an $L / S$ ratio of approximately $1 \mathrm{~L} \mathrm{~kg}^{-1}$. The measured emissions obtained by the column leaching tests at $L / S=2$ are also given in Table 1. In general, the results are consistent with the data from the pilot experiment. However, differences in the absolute values are evident and likely the result of variations between leaching behaviour under laboratory and field conditions. It should be noted that during a column leaching test, a large part of the waste packed in the column interacts with the percolating water or leachate. The interaction between waste and percolating water or leachate within the pilot experiment is smaller compared to conditions in a laboratory experiment. This process is also called preferential flow. Under laboratory conditions $100 \%$ of the pore volume can be flushed. In the Equifill pilot project it was estimated that after 5 years the leachate had only flushed approximately $25 \%$ of the pore volume (van Zomeren \& van der Sloot 2006a). Hence, variations in emissions of mobile constituents between column leaching tests and pilot-scale experiments can be explained by the differences in mobile or immobile fractions.

The Council decision 2003/33/EC (CEC 2003) states that values for total dissolved solids (TDS) can be used alternatively to the emissions of chloride and sulfate. As Ca leaching of the waste mixture amounts to $2000 \mathrm{mg} \mathrm{kg}^{-1}$ at $L / S=2$ it can be expected that TDS will not provide a solution for non-compliance with the acceptance criteria. Various sources (e.g. Kruempelbeck \& Ehrig 1999, Stegmann et al. 2003) indicate that nitrogen is a component that very often exceeds groundwater standards or surface water discharge standards for a very long time. The Council decision 2003/33/EC (CEC 2003) does not include limit values for nitrogen. The EU Groundwater Directive (CEC 2006) could introduce the necessity to determine limit values for nitrogen for inert waste landfills. Applying the same methods that were used for the establishment of acceptance criteria for inert waste and the groundwater standard of $50 \mathrm{mg} \mathrm{NO}_{3} \mathrm{~L}^{-1}$ a limit value for nitrate can be calculated. When an attenuation factor of 3 (similar to the attenuation factor that was taken for chloride) is used, it is expected that such a limit value at $L / S=2$ will be between 100 and $200 \mathrm{mg} \mathrm{NO}_{3} \mathrm{~kg}^{-1}$. At $L / S=0.9$ the pilot project has released $65 \mathrm{mg} \mathrm{NO}_{3} \mathrm{~kg}^{-1}$.

The results in Table 1 indicate that adequate pre-treatment measures such as flushing of salts could be taken and stricter acceptance criteria must be set in order to comply with the acceptance criteria for landfills accepting inert wastes. However, the comparison of measured emissions in leachate with acceptance does not account for local soil and groundwater conditions in the vicinity of the landfill. 
A so-called site-specific risk assessment, based on geochemical modelling and comparison of peak concentrations at a point of compliance with water quality criteria, is needed to properly address the local situation and associated risks of the landfill leachate. This approach is explained in the following section and an example is given of the calculated longterm emissions from the landfill, taking into account the local soil and groundwater conditions.

\section{Modelling long-term impact of a predomi- nantly inorganic waste landfill}

Landfills have widely varying waste composition and are situated in widely varying environmental conditions. In order to obtain a meaningful risk assessment for aftercare completion, site-specific parameters (e.g. groundwater quality) for the landfill in question need to be included.

For the purpose of establishing waste acceptance criteria in the Landfill Directive, a combination of several minimum standards for drinking water quality was taken as the basis for establishment of these criteria (Hjelmar et al. 2001). An imaginary drinking water well was therefore selected as the point of compliance (Figure 1). In this conceptual model, the contaminants from the landfill are transported through the underlying soil and groundwater towards the point of compliance. The models were based on reactive transport of contaminants using a distribution coefficient $\left(K_{\mathrm{d}}\right)$, implying that they only considered dilution and transport of contaminants in the soil and groundwater with a fixed retardation factor. It is well known and documented that during the transport of the leachate concentration reduction of contaminants can occur over time or distance from the source due to physical, chemical $(\mathrm{pH}$ and competition of other ions) and biological changes in the landfill. However, not all of these processes could be quantitatively considered in the models at that stage (e.g. adsorption of metals to organic matter, $\mathrm{pH}$ dependent leaching of contaminants due to solubility control by mineral phases).

Substantial progress in chemical reaction / transport modelling has been made over the last decade and it is now feasible to predict long-term emissions from application and/ or disposal scenarios, using advanced, thermodynamically consistent, geochemical models. Reactive transport modelling enables inclusion of more specific attenuation processes than have been considered in establishment of the waste acceptance criteria. A database/expert system has been developed to make this knowledge more accessible (van der Sloot et al. 2003, 2008).

In the Netherlands, the ministry of Spatial Planning, Housing and the Environment has recently revised the Dutch building materials decree (VROM 1995) using a state of the art scenario modelling approach (Verschoor et al. 2006). The new soil quality decree (VROM 2007) is derived from more detailed modelling assessments taking into account the chemical processes in the underlying soil system. In this study, the new modelling approach is applied for a sustainable landfill pilot experiment in the Netherlands (van Zomeren and van der Sloot 2006a, van Zomeren et al. 2009). The aim of this study is to demonstrate the effect of the local soil type on the projected long-term emission of contaminants and to provide a new basis for determination of landfill after-care criteria based on site specific environmental risk assessment.

The scenario involves a predominantly inorganic waste landfill (pilot experiment) without a liner system (Figure 3). The height of the landfill is $20 \mathrm{~m}$ and a net infiltration of $300 \mathrm{~mm}$ year $^{-1}$ was assumed (long-term average infiltration in The Netherlands) to calculate the impact of an uncovered landfill. The source term (concentration profile as a function of time) is given by the results of the upflow percolation leaching test (CEN TS 14405; (CEN 2005)) on the landfilled waste mixture. Using information on the height of the landfill, density of the waste and infiltration rate, the $L / S$ ratio from the laboratory test can be converted to a timescale. The concentration of contaminants entering the underlying soil system is input in the model calculations. The next part of the scenario description is the soil type. Three general soil types were selected for the model scenarios: sand, clay and peat. A summary of the generic soil properties can be found in van Zomeren et al. (2009) and in more detail in Verschoor et al. (2006). The released contaminants are transported through the underlying soil into the groundwater at certain depth. The transport of contaminants is calculated using various reactions and adsorption/complexation models ('multisurface' approach) as described in detail by Dijkstra et al. (2004, 2008). The impact of the released contaminants on the groundwater quality is subsequently calculated in the model.

The result of the modelling assessment is a timedependent concentration profile in the groundwater and comparison of the peak concentration with drinking water standards. An example of the modelling results for chloride, sulfate and copper as a function of time and distance from the landfill is presented in Figure 4. In this scenario, the groundwater at distances of $0.05,11.5$ and $29.5 \mathrm{~m}$ from the boundary of the landfill are taken as examples of the point of compliance (POC). It can be seen that sulfate and chloride leachate concentrations are well above the drinking water and groundwater limit concentrations at all distances from the landfill. The model calculations are consistent with the results of the leaching tests and the judgement based on the acceptance criteria for inert waste in that also chloride and sulfate were identified as the most important potential noncompliant constituents. The results could lead to the conclusion that the emissions are too high to complete aftercare of the landfill. However, the neighbouring Noordzeekanaal and the groundwater in the area of the landfill are brackish and contain concentrations of chloride (2500 to $5000 \mathrm{mg} \mathrm{Cl}^{-} \mathrm{L}^{-1}$ ) 


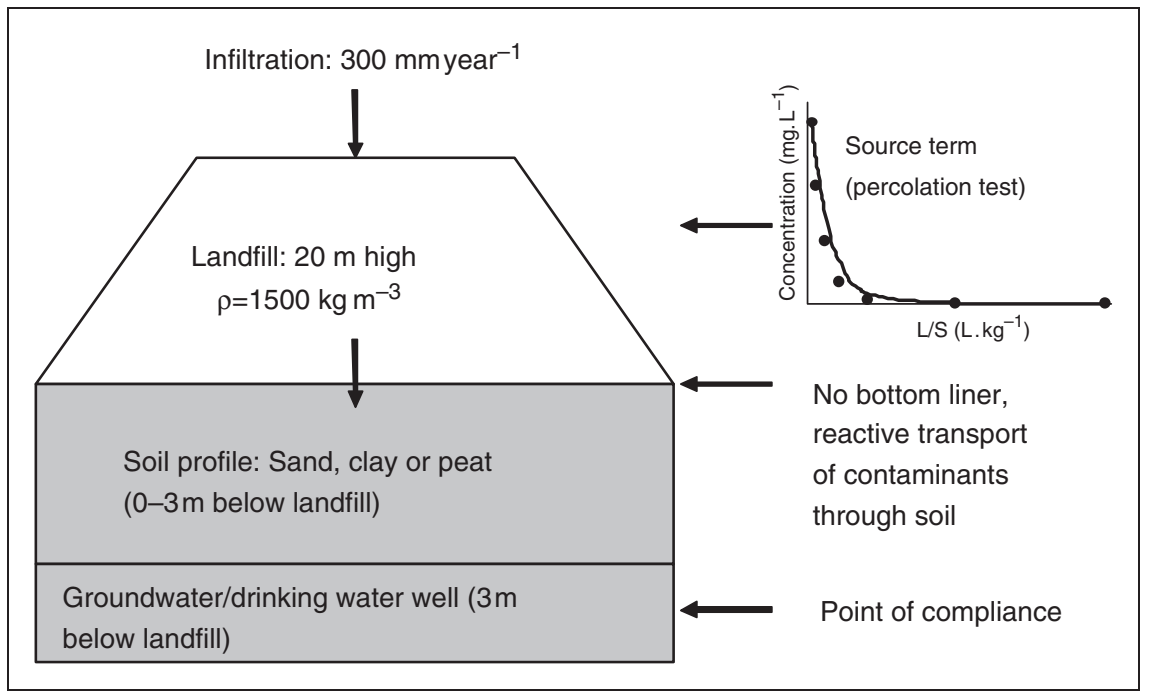

Figure 3. Principles of the reactive transport modelling approach applied on the Equifill landfill pilot.

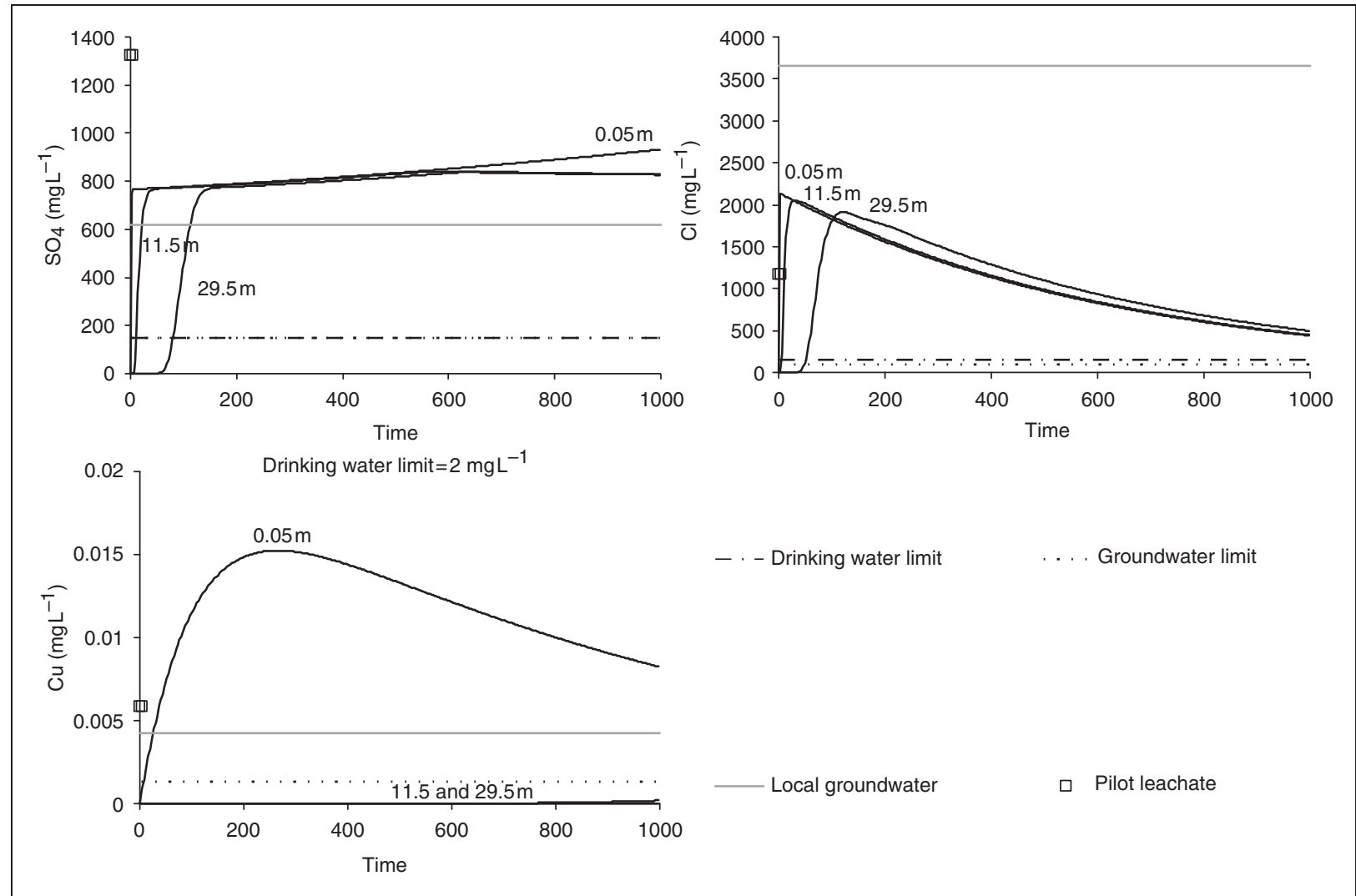

Figure 4. Predicted emissions of $\mathrm{Cl}^{-}, \mathrm{SO}_{4}{ }^{2-}$ and $\mathrm{Cu}$ at $0.05,11.5$ and $29.5 \mathrm{~m}$ from the landfill as a function of time.

and sulfate (500 to $700 \mathrm{mg} \mathrm{SO}_{4}{ }^{2-} \mathrm{L}^{-1}$ ) When the peak concentrations are subsequently compared with the local groundwater concentrations, it can be seen that the chloride and sulfate concentrations from the landfill are comparable (sulfate) or significantly lower (chloride) than the local (background) groundwater concentrations. The calculated $\mathrm{Cu}$ concentrations are well within the required drinking water and groundwater limits at 11.5 and $29.5 \mathrm{~m}$ from the landfill.
The groundwater in the specific area is not suitable for drinking. It could, therefore, be argued that chloride and sulfate are irrelevant constituents at the landfill site in question and that there is no need to meet drinking water limit concentrations.

Another aspect of site-specific risk assessment is that local soil types and properties can be taken into account. Model predictions of maximum concentrations in the groundwater at $3 \mathrm{~m}$ from the landfill are presented in Table 2 
Table 2. Comparison of predicted maximum groundwater concentrations with drinking water limits at $3 \mathrm{~m}$ (sand, peat, clay) and $20 \mathrm{~m}$ (sand) from the landfill after 500 years of infiltration $\left(300 \mathrm{~mm} \mathrm{yr}^{-1}\right.$ )

\begin{tabular}{|c|c|c|c|c|c|}
\hline Component & $\begin{array}{l}\text { Drinking water } \\
\text { limit (ppb) }\end{array}$ & $\begin{array}{l}\text { Sand, } 20 \mathrm{~m} \\
\text { (ppb) }\end{array}$ & $\begin{array}{l}\text { Sand, } 3 \mathrm{~m} \\
\text { (ppb) }\end{array}$ & $\begin{array}{l}\text { Clay, } 3 \text { m } \\
\text { (ppb) }\end{array}$ & $\begin{array}{l}\text { Peat, } 3 \mathrm{~m} \\
\text { (ppb) }\end{array}$ \\
\hline Ba & 625 & 4.8 & 6.8 & 5.7 & 5.5 \\
\hline SO4 & $1.5 E+05$ & $1.7 E+06$ & $1.7 E+06$ & 1.7E + 06 & 1.7E + 06 \\
\hline $\mathrm{Cl}$ & $1.5 E+05$ & $5.7 E+06$ & $7.4 E+06$ & $6.9 E+06$ & $7.3 E+06$ \\
\hline $\mathrm{Cd}$ & 5 & 4.3 & 47 & 0.001 & 0.8 \\
\hline $\mathrm{Cr}$ & 30 & 0.002 & 0.7 & 0.0004 & 0.0001 \\
\hline $\mathrm{Cu}$ & 75 & 0.0025 & 2.5 & 0.001 & 0.0001 \\
\hline $\mathrm{Ni}$ & 20 & 0.36 & 80 & 0.002 & 0.0001 \\
\hline $\mathrm{Pb}$ & 10 & 0.0085 & 1.9 & 0.002 & 0.0003 \\
\hline $\mathrm{Zn}$ & 800 & 6.3 & 430 & 0.001 & 0.0001 \\
\hline As & 10 & 0.0043 & 0.0011 & 0.00001 & 0.001 \\
\hline Mo & 70 & 7.1 & 9 & 8.1 & 8.5 \\
\hline $\mathrm{Sb}$ & 5 & 6.6 & 6.8 & 7.4 & 8.2 \\
\hline Se & 10 & 5.1 & 7 & 0.0003 & 6.3 \\
\hline Co & 100 & 0.76 & 2.4 & 0.006 & 0.02 \\
\hline Sn & 50 & 0.003 & 0.6 & 0.001 & 0.0002 \\
\hline V & 70 & 1.1 & 1.3 & $5 \mathrm{E}-07$ & 1.3 \\
\hline $\mathrm{Hg}$ & 0.3 & na & na & na & na \\
\hline $\mathrm{F}$ & 1100 & na & na & na & na \\
\hline
\end{tabular}

Bold numbers exceed the drinking water limit values.

na, not analysed.

(van Zomeren et al. 2009). In addition, a model calculation with a sandy soil (worst case) at $20 \mathrm{~m}$ from the landfill was also evaluated as a more realistic distance for a point of compliance. Table 2 shows the calculated maximum (peak) concentrations of contaminants over the whole period $(0-500$ years) for each soil type. The results for the mobile constituents chloride and sulfate exceed the drinking water limits in all scenarios and the implications have been discussed above.

In addition to the local groundwater conditions, preferential flow was not taken into account. It was found earlier (van Zomeren \& van der Sloot 2006a) that about 25\% of the landfill contributes to emissions of salts due to preferential flow paths. When these factors are taken into account, chloride concentrations would be in the same order of magnitude as the drinking water limits at $20 \mathrm{~m}$ from the landfill. In general, calculated concentrations of contaminants in groundwater are highest in the scenario with a sandy soil and lowest in the peat soil. The sandy soil has a relatively low $\mathrm{pH}$ and is limited in the amount of reactive $\mathrm{Fe} / \mathrm{Al}$ (hydr-)-oxides and organic matter. Therefore, concentrations of contaminants from the landfill are only slightly adsorbed to the sandy soil. The clay and peat soils have a higher $\mathrm{pH}$ and contain more reactive surface sites for adsorption of contaminants (van Zomeren et al. 2009).

Cadmium and nickel are relatively mobile in an acidic sandy soil and exceed the drinking water limits at 3 from the landfill. However, the concentrations in groundwater stay well below the drinking water limits at $20 \mathrm{~m}$ from the landfill and when the scenario is calculated for a clay or peat soil. Antimony concentrations reach the drinking water limit for all three soil types (at 3 and $20 \mathrm{~m}$ ) in this modelling scenario.

The concentrations of all other relevant elements ( $\mathrm{Hg}$ and $F$ were not analysed) remain well below the drinking water limit already at $3 \mathrm{~m}$ from the landfill. The modelling approach enables identification of possible critical contaminant emissions from landfills and could facilitate site-specific assessments of these emissions to determine the degree of aftercare and/or decisions on the aftercare period. The presented approach consists of the conceptual model that was used to derive acceptance criteria for landfills. Recently, a more state-of-the-art model has been used for calculation of limit values for the application of (secondary) construction products in the Netherlands. It is important to mention that more complex models for describing reactive transport processes also require more input data and information about the system to be modelled. This will impose an extra monitoring and registration demand for the landfill operator. Assumptions on boundary conditions (e.g. release rates, steady state versus non-stationary flows, future conditions) often dominate the model estimates and represent major sources of uncertainty. Model assumptions and uncertainties need specific attention in order to reach a level of reliability for model estimates that is acceptable for regulators. In the future data gathering will start when the first truckload of waste is accepted. During some 20 years of operation and 
30 years of compulsory aftercare data time series can be compiled that can be used to verify model estimates. The presented modelling approach might provide a basis for application when the acceptance criteria for landfill will be revised in the future. In addition, the modelling approach can be used as one of the toolboxes to perform assessments of the long-term emissions from landfill leachates and might help the competent authorities to decide whether the remaining emission potential is acceptable or not.

\section{Conclusions}

Progress in knowledge of landfill processes and geochemical modelling has enabled site-specific long-term emission predictions. This paper illustrates that 'stable situation' and 'final storage quality' are aspects that cannot be defined entirely by means of absolute numbers. Acceptable emissions and limit values should depend on the local situation (e.g. soil and groundwater conditions). A rigid definition of leaching limit values does not always coincide with a realistic impact assessment. In order to end aftercare, the landfill operator needs to prove to the competent authority that the landfill no longer poses a threat to the environment. A list of limit values can only achieve this if large (possibly unattainable) safety margins are introduced. This could result in unnecessary costs for society. Competent authorities and landfill operators could therefore benefit from a robust site-specific risk assessment method.

Recent developments in British and German landfill regulations are very positive. They do provide more clarity concerning aftercare completion. The legislators have also realized that it is possible to actively reduce potential longterm emissions. The regulations provide possibilities for operators to apply measures to accelerate aftercare completion. Rather than making it redundant, these developments underline the need for a robust site-specific risk assessment method.

Preferably, such a method takes the entire landfill (cell) into account instead of just individual waste batches. Moreover, the method should account for different soil and groundwater conditions as the site selection of landfills is an important aspect of sustainability. The approach used for the establishment of the acceptance criteria of the Annex II of the European Landfill Directive can provide a starting point for the development of a robust risk assessment method.

Dutch operators and regulators intend to develop 'endpoint' criteria as described above. A standardized assessment method for release from aftercare is currently not available. However, recent developments in modelling indicate that such an approach is feasible and the approach was presented in this study. The presented modelling approach might provide a basis for application when the acceptance criteria for landfill will be revisited in the future. In addition, the modelling approach can be used as one of the toolboxes to perform assessments of the long-term emissions from landfill leachates and might help the competent authorities to decide whether the remaining emission potential is acceptable or not. However, it is necessary to define which aspects can and should be added and what level of reliability is required for prediction of long term emission potential. Moreover, the results imply that local environmental conditions contribute to the acceptability of landfill emissions and are important factors in choosing a landfill location.

\section{References}

BMU (2009) Verordnung zur Vereinfachung des Deponierechts. Bundesgesetzblatt 22(1, G5702), pp. 900-950. BMU, Bonn, Deutschland.

CEC (1999) Council Directive 1999/31/EC of 26 April 1999 on the Landfill of Waste. Official Journal of the European Communities.

CEC (2003) Council Decision 2003/33/EG of 19 December 2002 establishing Criteria and Procedures for the Acceptance of Waste at Landfills Pursuant to Article 16 and Annex II of Directive 1999/ $31 /$ EC on the Landfill of Waste. Official Journal of the European Communities.

CEC (2005) Taking Sustainable Use of Resources Forward: A Thematic Strategy on the Prevention and Recycling of Waste, Communication from the Commission to the Council, the European Parliament, the European Economic and Social Committee and the Committee of the Regions, COM(2005) 666 final. Official Journal of the European Communities.

CEC (2006) Directive 2006/118/EC of the European Parliament and of the Council of 12 December 2006 on the Protection of Groundwater against Pollution and Deterioration, Official Journal of the European Communities. Official Journal of the European Communities.

CEC (2008): Directive 2008/98/EC of the European Parliament and of the Council of 19 November 2008 on waste and repealing certain Directives), L312/3-30, 22.11.2008, Official Journal of the European Communities. Official Journal of the European Communities.

CEN (2005) TS 14405, (2005): Characterisation of waste - Leaching behaviour tests - Upflow percolation test, CEN.

Dijkstra JJ, Meeussen JCL and Comans RNJ (2004) Leaching of heavy metals from contaminated soils; an experimental and modelling study. Environmental Science \& Technology 38: 4390-4395.

Dijkstra JJ, Meeussen JCL, van der Sloot HA and Comans RNJ (2008) A consistent geochemical modelling approach for the leaching and reactive transport of major and trace elements in MSWI bottom ash. Applied Geochemistry 23: 1544-1562.

Dijkstra JJ, Meeussen JCL and Comans RNJ (2009) Evaluation of a generic multisurface sorption model for inorganic soil contaminants. Environmental Science \& Technology 43: 6196-6201.

Environment Agency (2005) Guidance on Landfill Completion and Surrender. Bristol, UK: Environment Agency, DRAFT.

Hjelmar O and Bjerre Hansen J (2005) Sustainable landfill: the role of final storage quality. In: CISA, Environmental Sanitary Engineering Centre, Cagliari, Italy, S. Margherita di Pula, Cagliari, Italy.

Hjelmar O, van der Sloot HA, Guyonnet D, Rietra RPJJ, Brun A and Hall D (2001) Development of acceptance criteria for landfilling of waste: an approach based on impact modelling and scenario calculations. In: CISA, Environmental Sanitary Engineering Centre, Cagliari, Italy, S. Margherita di Pula, Cagliari, Italy, pp. 711-721.

ITRC (Interstate Technology \& Regulatory Council) (2006) Evaluating, Optimizing, or Ending Post-Closure Care at MSW Landfills Based on Site-Specific Data Evaluations. ALT-4. Interstate Technology \& Regulatory Council, Alternative Landfill Technologies Team. Washington, DC, www.itrcweb.org.

Kruempelbeck I and Ehrig HJ (1999): Long-term behaviour of municipal solid waste landfills in Germany. In: CISA, Environmental 
Sanitary Engineering Centre, Cagliari, Italy, S. Margherita di Pula, Cagliari, Italy, pp. 27.

Luning L, van Zundert EHM and Coops O (2006) Bioreactor, stortplaats voor overwegend organisch afval, Dutch Sustainable Landfill Foundation, Den Bosch, The Netherlands. http:// www.duurzaamstorten.nl/wawcs0122291/ln-publications.html Accessed 25 May 2010.

Mathlener RA, Heimovaara T, Oonk H, Luning L, van der Sloot HA and van Zomeren A (2006) Opening the Black Box, Process-based Design Criteria to Eliminate Aftercare of Landfills. pp. 1-78, Dutch Sustainable Landfill Foundation, Den Bosch, The Netherlands, http://www.duurzaamstorten.nl/wawcs0122291/ln-publications.html. Accessed 25 May 2010.

Meeussen JCL (2003) ORCHESTRA: An object-oriented framework for implementing chemical equilibrium models. Environmental Science \& Technology 37: 1175-1182.

Scharff H (2006) ICLRS4 Session report: Integrated discussion on landfill stabilisation and sustainable landfill. In: Proc. 4th Intercontinental Landfill Research Symposium, 14-16 June, Gällivare, Sweden. Luleå Technical University, Luleå, Sweden.

Scharff H (2009) IWWG Sustainable Landfilling Task Group workshop report. In: CISA, Environmental Sanitary Engineering Centre, S. Margherita di Pula, Cagliari, Italy.

Scharff H and Jacobs J (2005) Equifill: inorganic waste landfill meeting EU landfill criteria. In: Sardinia 2005 Tenth International Waste Management and Landfill Symposium, 3-7 October 2005, Cagliari, Italy.

Scharff H, Jacobs J, van der Sloot HA, and van Zomeren A (2007) Inorganic waste landfill and final storage quality. In: CISA, Environmental Sanitary Engineering Centre, Cagliari, Italy, S. Margherita di Pula, Cagliari, Italy, pp. 147-148.

Stegmann R, Heyer KU, Hupe K and Ritzkowski M (2003) Discussion of criteria for the completion of landfill aftercare. In: CISA, Environmental Sanitary Engineering Centre, Cagliari, Italy, S. Margherita di Pula, Cagliari, Italy, pp. 183-185.

Stegmann R, Heyer KU, Hupe K and Willand A (2006) Deponienachsorge - Handlungsoptionen, Dauer, Kosten und quantitative Kriterien für die Entlassung aus der Nachsorge. UFOPLANNr. 20434 327, 1-172. Bundesministerium für Umwelt, Naturschutz und Reaktorsicherheit, Bonn, Deutschland.

van der Sloot HA, Seignette P, Comans RNJ, van Zomeren A, Dijkstra JJ, Meeussen JCL, Kosson DS and Hjelmar O (2003) Evaluation of Environmental Aspects of Alternative Materials using an Integrated Approach assisted by a Database/expert System. Dundee, Scotland: University of Dundee, 769-790.

van der Sloot HA, van Zomeren A, Meeussen JCL, Seignette P and Bleijerveld R (2007) Interpretation of test method selection, validation against field data, and predictive modelling for impact evaluation of stabilised waste disposal. Journal of Hazardous Materials 141: 354-369. van der Sloot HA, Seignette PFAB, Meeussen JCL, Hjelmar O, and Kosson DS, (2008) A Database, Speciation Modelling and Decision Support Tool for Soil, Sludge, Sediments, Wastes and Construction Products: Leachxs ${ }^{T M}$ - Orchestra. CISA, Environmental Sanitary Engineering Center, Venice, Italy.

van Zomeren A and van der Sloot HA (2006a) Equifill, Landfill Site for Predominantly Inorganic Waste, pp. 1-101. Dutch Sustainable Landfill Foundation, Den Bosch, The Netherlands, http:// www.duurzaamstorten.nl/wawcs0122291/ln-publications.html. Accessed 25 May 2010.

van Zomeren A and van der Sloot HA (2006b) Monolith, Stortplaats voor cement-gestabiliseerd gevaarlijk afval. Dutch Sustainable Landfill Foundation, Den Bosch, The Netherlands, http:// www.duurzaamstorten.nl/wawcs0122291/ln-publications.html. Accessed 25 May 2010.

van Zomeren A, Meeussen JCL, Oonk H, Luning L, and van der Sloot HA (2006) Evaluation of Geochemical and Biochemical Processes and Release from Landfills, pp. 1-100. Dutch Sustainable Landfill Foundation, Den Bosch, The Netherlands, http://www.duurzaamstorten.nl/ wawcs0122291/ln-publications.html. Accessed 25 May 2010.

van Zomeren A, van den Berg P, Bleijerveld, R and van der Sloot HA (2007) Identification of in-situ processes controlling emissions of a stabilised waste landfill by field measurements and geochemical modelling. In: CISA, Environmental Sanitary Engineering Centre, Cagliari, Italy, S. Margherita di Pula, Cagliari, Italy, pp. 583-584.

van Zomeren A, Scharff H and van der Sloot HA (2009) Environmental risk assessment for determination of long-term emissions of landfills. In: CISA, Environmental Sanitary Engineering Centre, Cagliari, Italy, S. Margherita di Pula, Cagliari, Italy, pp. 231-232.

Verschoor AJ, Lijzen JPA, van den Broek HH, Cleven RFMJ, Comans RNJ, Dijkstra JJ and Vermij PHM (2006): Kritische emissiewaarden voor bouwstoffen; milieuhygienische onderbouwing en consequenties voor bouwmaterialen. RIVM report 711701043/2006, pp. 1-295. RIVM, Bilthoven, The Netherlands.

Verschoor AJ, Lijzen JPA, van den Broek HH, Cleven RFMJ, Comans RNJ and Dijkstra JJ (2008) Revision of the Dutch building materials decree: alternative emission limit values for inorganic components in granular building materials. In: 9th International Symposium on Environmental Geotechnology and Global Sustainable Development, 2-4 June 2008, Hong Kong.

VROM (1995) Dutch Building Materials decree. Besluit van 23 november 1995, houdende regels met betrekking tot het op of in de bodem of in het oppervlaktewater gebruiken van bouwstoffen (Bouwstoffenbesluit bodem- en oppervlaktewaterenbescherming). Staatsblad van het Koninkrijk der Nederlanden 567: 1-92.

VROM (2007) Dutch Soil Quality Decree (Besluit Bodemkwaliteit). Staatsblad van het Koninkrijk der Nederlanden 2007 p. 469.

WCED (1987) Our Common Future, Report of the World Commission on Environment and Development. Oxford, UK: Oxford University Press, $1-400$. 